\title{
Selective apoptotic effect of Zelkova serrata twig extract on mouth epidermoid carcinoma through p53 activation
}

\author{
Hoe-Jin Kang and Young-Joo Jang
}

Apoptosis or programmed cell death plays an essential role in chemotherapy-induced tumor cell killing, and inducers of apoptosis are commonly used in cancer therapy. Treatment with Zelkova serrata extracts was performed in human gingival fibroblast (HGF), mouth epidermoid carcinoma cell (KB), lower gingival squamous cancer cell (YD38) and tongue mucoepidermoid carcinoma cells (YD15). We observed that extract prepared from Zelkova serrata twig selectively inhibited proliferation of various oral cancer cells, but not normal gingival fibroblasts, in a dose-dependent manner. Caspase-8-mediated apoptosis was induced by treatment with the extract only in mouth epidermoid carcinoma and not in other types of cancer cells, including lower gingival squamous cell carcinoma. The selective apoptotic effect of Zelkova serrata twig extract in mouth epidermoid carcinoma was dependent on normal p53 status. Apoptosis was not remarkably induced by treatment with the extract in either lower gingival squamous or tongue mucoepidermoid carcinoma cells, both of which contain abnormalities of p53. Upon treatment with Zelkova serrata twig extract, mouth epidermoid carcinoma cells accumulated in S phase by activation of p21. These data indicate that Zelkova serrata twig extract exerted a cancer type-specific, p53-dependent apoptotic effect and disturbed the cell cycle, which suggests that herbal medicine could be a treatment for specific types of cancers.

International Journal of Oral Science (2012) 4, 78-84; doi:10.1038/ijos.2012.14; published online 13 April 2012

Keywords: anticancer; apoptosis; oral carcinomas; p53; Zelkova serrata

\section{INTRODUCTION}

Oral cancer is the sixth most common cancer in the world and the third most common cancer in Asia with an average incidence rate of 110 per 100000 people. $^{1}$ The incidence of oral cancer is increasing in developed countries. Oral cancer constitutes a serious health problem, as evidenced by its poor survival rates and severe functional and cosmetic defects resulting from this cancer and its treatment. Despite significant medical advances in the treatment of oral cancer over the past 30 years, the 5 -year survival rate of this cancer remains low at approximately $50 \% .^{2}$ Especially, squamous cell carcinoma of the oral cavity is a severe cancer type as patients fail to respond to treatment frequently. ${ }^{3}$ In this situation, development of an oral cancer-specific, anti-cancer drug is needed. Apoptosis is an essential process in the physiology of normal development and in the maintenance of constant cell numbers. As numerous cancers are caused by improper cell death, cancer cell-specific inducers of apoptosis are being developed as anti-cancer agents. These studies suggested that induction of apoptosis has become a principal mechanism through which anticancer therapy exerts its effects. ${ }^{4-5}$ Caspase- 8 is an upstream caspase that is activated by a receptor-mediated pathway through the external apoptotic pathway. ${ }^{6}$ Caspase- 9 is the primary caspase in the mitochondriainitiated apoptosis pathway and requires release of cytochrome $\mathrm{C}$ from mitochondria as well as interaction with Apaf-1. This internal apoptotic pathway, which is associated with changes in the permeability of the outer mitochondrial membrane and the collapse of membrane potential, results in release of cytotoxic proteins and caspase activation. ${ }^{7-8}$ Caspases- 8 and -9 activate downstream effector caspases such as caspase- 3 and therefore play a pivotal role in the induction of apoptosis. As a key tumor suppressor, p53 plays a critical role in tumor prevention. In response to various stress signals, p53 selectively regulates a set of target genes and initiates various stress responses, including cell cycle arrest, apoptosis and/or senescence, to exert its tumor suppression function..$^{9-13}$ Generally, $p 53$ is the most frequently mutated gene in human tumors, and $p 53$ mutations occur in more than $50 \%$ of all tumors. Disruption of normal p53 function is often a prerequisite for the development and/or progression of tumors. ${ }^{14-15}$ Specifically, p53 triggers cell cycle arrest through specific transcriptional activation of the cyclin-dependent kinase inhibitor p21 (also known as $\mathrm{p} 21^{\mathrm{WAF} 1 / \mathrm{Cip} 1}$, which promotes cell cycle arrest in response to many stimuli. ${ }^{16-17}$ Additionally, biochemical and genetic studies have indicated that p21 acts as a master effector for promoting antiproliferative activities that are independent of the classical p53 tumor suppressor pathway. ${ }^{18}$ These reports suggested that, paradoxically, p21 might also promote apoptosis through both p53-dependent and p53-independent mechanisms under certain cellular stresses. Use of natural products has increased based on their potential

Laboratory of Cell Cycle and Signal Transduction, World Class University Research Department of Nanobiomedical Science and Institute of Tissue Regeneration Engineering, Dankook University, Cheonan, Korea

Correspondence: Dr YJ Jang, Laboratory of Cell Cycle and Signal Transduction, World Class University Research Department of Nanobiomedical Science and Institute of Tissue Regeneration Engineering, Dankook University, 29 Anseo-Dong, Cheonan 330-714, Korea

E-mail: yjjang@dankook.ac.kr

Received 5 December 2011; Accepted 13 December 2011 
chemotherapeutic activity. Especially, medical plants are widely used in drug development as anti-cancer and anti-inflammatory agents, health food materials and resources of new functional materials. Zelkova serrata is a deciduous tree with very slender, zigzag-shaped, and red-brown twigs that contain widely divergent, pointed and coneshaped buds, and it is found growing naturally in Japan, Korea and Taiwan. ${ }^{19}$ Young leaves of $Z$. serrata are cooked to make vegetables, whereas its bark and leaves are used medicinally. Whole tree extract of $Z$. serrata is also widely used for the treatment of cancer. ${ }^{19}$ For example, a cadalene compound extracted from this tree was shown to possess antioxidant effects based on inhibition of lung tumorigenesis in mice. ${ }^{20-21}$ Even though the whole tree of $Z$. serrata, including the bark and leaves, is often used to treat various diseases, ${ }^{19,22}$ there have been no reports on the specific uses of twigs of $Z$. serrata. Therefore, the goals of this study were to examine the effects of methanol extract and fractions of $Z$. serrata twig on various oral cancer cell growths and to investigate the signal pathway mediating $Z$. serratainduced growth inhibition in oral cancer cells. For this, we used human oral cancer cell lines, such as mouth epidermoid carcinoma cells, lower gingival squamous cancer cells and tongue mucoepidermoid carcinoma cells, to investigate the anti-cancer activities of extract and fractions of $Z$. serrata and elucidate their selective apoptotic effects on specific types of oral cancers.

\section{MATERIALS AND METHODS}

\section{Preparation of extracts}

Twigs of $Z$. serrata were collected, dried at room temperature naturally and powdered. The powders were extracted with $100 \%$ methanol twice at room temperature in a magnetic forced stirrer. By using an accelerated solvent extractor, the extracts were filtered and concentrated to remove methanol at $74{ }^{\circ} \mathrm{C}$ and freeze dried. Of the dry extract, $50 \%$ was water-soluble, $40 \%$ was soluble in ethyl acetate and $\sim 10 \%$ was soluble in hexane. The ethyl acetate-soluble fraction containing a cancer-specific cytotoxicity was used for further study.

\section{Cell lines and culture}

Human oral carcinoma cell lines, such as mouth epidermoid carcinoma cell (KB), lower gingival squamous cancer cell (YD38) and tongue mucoepidermoid carcinoma cells (YD15) were obtained from Korea Cell Line Bank (KCLB, http://cellbank.snu.ac.kr). Human gingival fibroblast (HGF) was cultured primarily from tissue around an extracted tooth with the consent of patient. Cancer cells and primary cells were maintained in Dulbecco's modified Eagle medium and $\alpha$ minimum essential medium, respectively. Both cell cultures were supplemented with $10 \%$ fetal bovine serum (Hyclone, Logan, UT, USA), and maintained in a humidified atmosphere of $5 \% \mathrm{CO}_{2}$ at $37{ }^{\circ} \mathrm{C}$.

\section{Cell cytotoxicity test}

The cytotoxicity of twig extracts of $Z$. serrata on both oral carcinoma and primary cells was determined by using Cell Counting Kit-8 (CCK8; Dojindo, Kumamoto, Japan). Briefly, cells were seeded in $100 \mu \mathrm{L}$ of medium in 96 -well plate $\left(5 \times 10^{4}\right.$ cells per well). After incubation overnight, extracts were added in various concentrations $(0.01,0.1,1$, 20, 100,500 and $\left.2000 \mathrm{ng} \cdot \mu \mathrm{L}^{-1}\right)$ for indicated times, and then the cytotixicity test was performed. $10 \mu \mathrm{L}$ CCK-8 solution was added to each well, and cultivated for another $2-4 \mathrm{~h}$. By using a microplate reader (Molecular Device, Sunnyvale, CA, USA), soluble tetrazolium salt (WST-8, 2-(2-methoxy-4-nitrophenyl)-3-(4-nitrophenyl)-5-(2,4disulfophenyl)-2H-tetrazolium, monosodium salt) was measured as absorbance at $450 \mathrm{~nm}$.

\section{Sequence analysis of $p 53$ gene}

Total RNA was isolated from three kinds of oral carcinoma cell lines by using total RNA extraction kit (Intron Biotechnology, Seongnam-si, Korea) according to the manufacturer's instructions. Then cDNAs were synthesized from total RNAs with the cDNA synthesis kit (Intron biotechnology). The exponential phase in reverse transcriptional PCR was determined on 15-30 cycles to allow semiquantitative comparisons among cDNAs developed from identical reactions. PCR regime involved a 2 -min initial denaturation step at $94{ }^{\circ} \mathrm{C}$ for $30 \mathrm{~s}$, $55-59{ }^{\circ} \mathrm{C}$ for $30 \mathrm{~s}$ and $72{ }^{\circ} \mathrm{C}$ for $1 \mathrm{~min}$. Primer sequences were for $p 53$ : axon1 forward, 5'-ATGGAGGAGCCGCAGTCA-3', axon1 reverse, 5'-CATCGCTATCTGAGCAGC-3'; axon2 forward, 5' -GTCTGGCC CCTCCTCAGC-3', axon2 reverse, 5'-CTGAAGGGTGAAATATTC3'; axon3 forward, 5' -ATCCGTGGGCGTGAGCGC-3', axon3 reverse, $5^{\prime}$-TCAGTCTGAGTCAGGCCC-3'. PCR products were separated by electrophoresis on $1 \%$ agarose gels, and used for DNA sequencing reaction.

\section{Western blot and antibodies}

Whole cells were lysed in a lysis buffer $(0.5 \%$ Nonidet P-40; $120 \mathrm{mmol} \cdot \mathrm{L}^{-1} \mathrm{NaCl} ; 20 \mathrm{mmol} \cdot \mathrm{L}^{-1}$ Tris $-\mathrm{HCl}, \mathrm{pH} 8.0 ; 2 \mathrm{mmol} \cdot \mathrm{L}^{-1}$ EDTA, $\mathrm{pH}$ 8.0; $2 \mathrm{mmol} \cdot \mathrm{L}^{-1}$ EGTA, $\mathrm{pH}$ 8.0; protease inhibitors), and protein concentration of lysates was determined by using protein assay kit (BioRad, Hercules, CA, USA). ${ }^{23}$ Cell lysates were subjected to SDS-PAGE on $10 \%$ gel. The proteins were then electrophoretically transferred to polyvinylidene difluoride membrane (Millipore, Billerica, MA, USA), and blocked in TBST buffer with 5\% skim milk. The blots were then probed with primary antibodies, and incubated with horseradish peroxydase-conjugated secondary antibodies (Amersham Bioscience, Uppsala, Sweden). Signals were visualized using enhanced chemiluminescence reagent (ECL; Amersham Biosciences). Antibodies for caspase-3, caspase-8, caspase-9, PARP-1 and p21 were obtained from Santa Cruz Biotechnology. Anti-p53 and various anti-phospho-p53 antibodies were purchased from Cell Signaling.

\section{Fluorescence-activated cell sorting analysis}

Trypsinized cells were collected by centrifugation and fixed in ice-cold $80 \%$ ethanol. Cells were washed with PBS, stained with propidium iodide $\left(40 \mu \mathrm{g} \cdot \mathrm{mL}^{-1}\right)$ and $100 \mu \mathrm{g} \cdot \mathrm{mL}^{-1} \mathrm{RNase}$, and were analyzed in 10000 events by flow cytometry (FACSCaliber; Becton Dickinson, Franklin Lakes, NJ, USA). Histograms by flow cytometry were generated in Cell Quest program (Becton Dickinson), and analyzed by ModFit software (Becton Dickinson).

\section{RESULTS}

Z. serrata twig extract has significant cytotoxicity on human oral carcinoma cell lines

To investigate whether or not primary methanol extract of $Z$. serrata twigs has cytotoxic effects on normal primary and oral cancer cells, various concentrations of the methanol extract were treated to cells and the number of viable cells was measured by cytotoxicity test (Figure 1). Methanol extract showed a dose-dependent cytotoxic effect on cells from mouth epidermoid carcinoma, lower gingival squamous cancer and tongue mucoepidermoid carcinoma (Figure 1, $\mathrm{KB}$, YD38 and YD15). The $\mathrm{IC}_{50}$ in mouth epidermoid carcinoma cells (KB) was 200-250 ng $\mu \mathrm{L}^{-1}$ upon treatment with the methanol extract for $18 \mathrm{~h}$. Reversely, methanol extract did not show a cytotoxic effect on normal cells cultured from gingival tissue (Figure 1, HGF). 


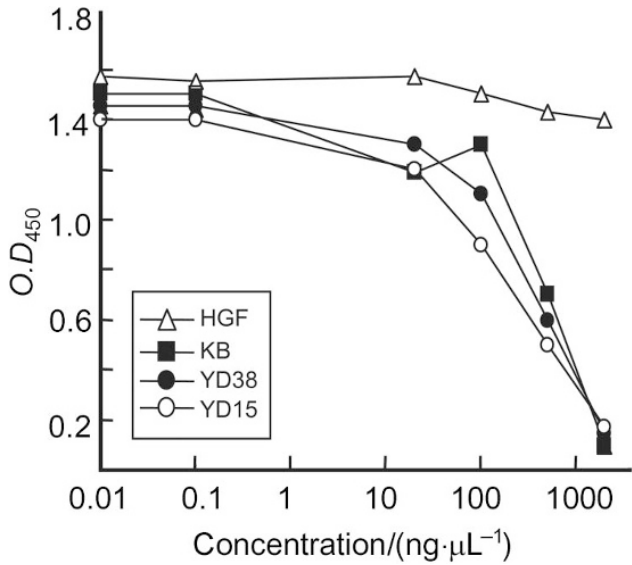

Figure 1 A dose-dependent cytotoxic effect was induced by primary methanol extract of Zelkova serrata twigs. After the various dose of methanol extract treatment, cell viability was assayed using Cell Counting Kit-8 as described in the section on 'Materials and methods'. Cells originated from mouth epidermoid carcinoma (KB, squares), lower gingival squamous cancer (YD38, filled circles) and tongue mucoepidermoid carcinoma (YD15, open circles) were treated with methanol extract for $18 \mathrm{~h}$. HGF indicated human gingival fibroblast, which is used for normal control.

The primary methanol extract was further partitioned into three fractions according to the solvent (hexane, ethyl acetate and water). The ethyl acetate fraction (EtOAc fraction) showed a dose-dependent cytotoxic effect on cells from mouth epidermoid carcinoma, and the $\mathrm{IC}_{50}$ in $\mathrm{KB}$ cells was $20 \mathrm{ng} \cdot \mu \mathrm{L}^{-1}$ upon treatment with the EtOAc fraction for $18 \mathrm{~h}$ (Figure $2 \mathrm{a}, \mathrm{KB}$ ), indicating an approximately 10 -fold increase in $\mathrm{IC}_{50}$ by the partition process. The cytotoxic effect of the EtOAc fraction on mouth epidermoid carcinoma cells was further analyzed according to morphological changes in response to treatment. The EtOAc fraction induced severe cell death at $20 \mathrm{ng} \cdot \mu \mathrm{L}^{-1}$, and most of the cells were detached from the culture dish at $18 \mathrm{~h}$ after treatment (Figure 2b-II).

\section{Z. serrata twig extract has selective apoptotic activity in oral carcinoma cells}

To examine whether or not these cytotoxic effects were the result of apoptosis, the methanol extract $\left(200 \mathrm{ng} \cdot \mu \mathrm{L}^{-1}\right)$ and its three fractions (each of $20 \mathrm{ng} \cdot \mu \mathrm{L}^{-1}$ ) prepared from the second partitioning were treated to primary and cancer cells for $24 \mathrm{~h}$. When mouth epidermoid carcinoma $(\mathrm{KB})$ cells were treated with both the methanol extract and EtOAc fraction, the levels of procaspases-3 and -8 decreased (Figure 3a, lanes 1 and 3), suggesting that cleavage of procaspases increased and the apoptosis pathway was activated. As a positive control for the detection of apoptosis, $10 \mu \mathrm{mol} \cdot \mathrm{L}^{-1}$ camptothesin was applied. Indeed, the levels of the procaspases intensively decreased according to treatment with camptothecin (Figure 3a, lane 5). Conversely, other fractions partitioned from the methanol extract, such as the hexane and water fractions, had no effects on caspase activation (Figure 3a, lanes 2 and 4). In the case of tongue mucoepidermoid carcinoma cells (YD15), there was only a slight decrease in the levels of these proteins, suggesting that induction of apoptosis occurred very weakly upon treatment with both the methanol extract and EtOAc fraction (Figure 3b, lanes 1 and 3). On the contrary, the levels of procaspases did not remarkably change upon treatment with any of the twig fractions or camptothecin in lower gingival carcinoma cells (YD38) (Figure 3c, lanes 1-5), suggesting that this cell line might have resistance to apoptosis inducers.
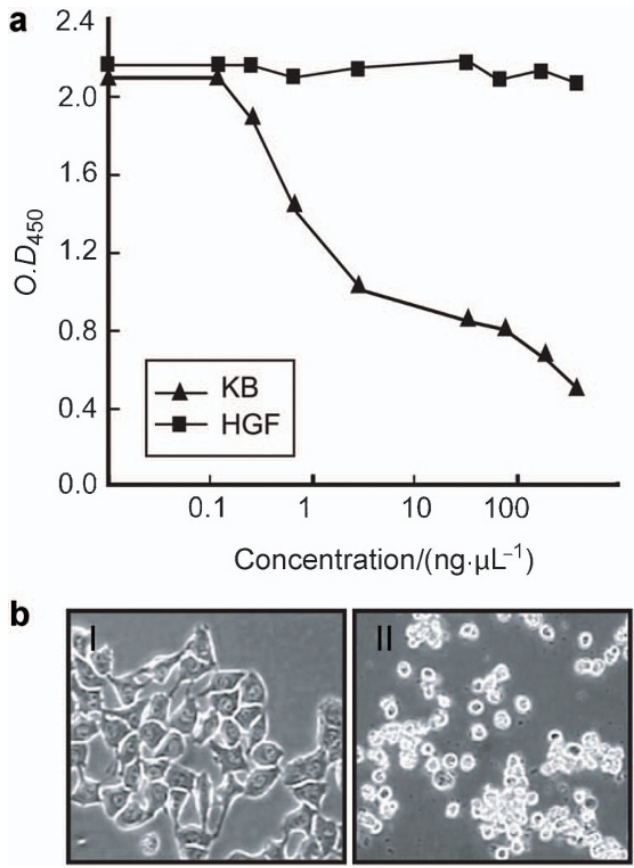

Figure 2 A dose-dependent cytotoxic effect was induced by ethyl acetate fraction purified by secondary partition of primary twig methanol extract. (a) The primary methanol extract was further partitioned into three fractions according to solvents, such as hexane, ethyl acetate and water. The ethyl acetate fraction (EtOAc fraction) showed a dose-dependent cytotoxic effect on mouth epidermoid carcinoma cells (KB, triangles), but not on primary gingival fibroblast (HGF, squares). (b) Morphological changes of mouth epidermoid carcinoma cells caused by treatment with EtOAc fraction. (I) KB cells untreated with EtOAc fraction; (II) KB cells treated with EtOAc fraction (20 $\mathrm{ng} \cdot \mu \mathrm{L}^{-1}$ for $18 \mathrm{~h}$ ).

Additionally, to confirm the selective apoptotic effect of the EtOAc fraction of $Z$. serrata twig extract on mouth epidermoid carcinoma cells, we analyzed the cleavage products of active caspase- 3 and poly(ADP-ribose)-polymerase (PARP-1). When lower gingival squamous (YD38) and epidermoid (KB) cells were treated with $20 \mathrm{ng} \cdot \mu \mathrm{L}^{-1}$ of the EtOAc fraction for $24 \mathrm{~h}$, active fragments of the apoptotic proteins were detected in $\mathrm{KB}$ cell lysate (Figure 4a, lane 2 in upper and middle panels). There are two major apoptotic pathways, the caspase-8coupled death receptor pathway and the caspase-9-coupled intrinsic mitochondrial pathway with crosstalk between them. ${ }^{6-8}$ To determine which apoptotic pathway is induced by treatment with $Z$. sarrata extract in KB cells, we examined the active cleavage of caspase- 8 and caspase-9. When EtOAc fractions of twig extract and camptothecin were applied to $\mathrm{KB}$ epidermoid carcinoma cells for $24 \mathrm{~h}$, active fragments of caspase- 8 were observed in the cell lysates (Figure $4 \mathrm{~b}$, lanes 2 and 3 in upper panel). However, under the same conditions, caspase- 9 activation was not detected at all in either lysate (Figure $4 \mathrm{~b}$, lanes 2 and 3 in middle panel). These data suggest that $Z$. serrata twig extract induced the caspase-8-dependent external apoptotic pathway in an epidermoid carcinoma cell-specific manner.

\section{p53 activation is involved in $Z$. serrata twig extract-induced apoptosis}

Modulation of apoptosis by treatment with twig extract was observed in mouth epidermoid carcinoma cells, but not in the other two types of oral cancer cells. Based on this selective apoptotic effect, we analyzed the differences in the molecular aspect of $\mathrm{p} 53$ protein among the three 


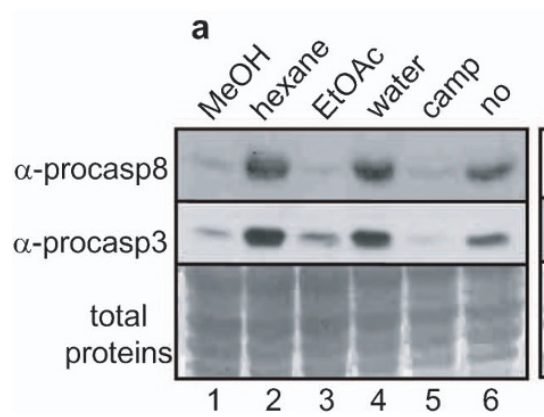

b

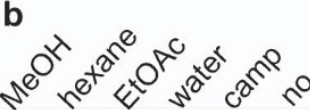

C
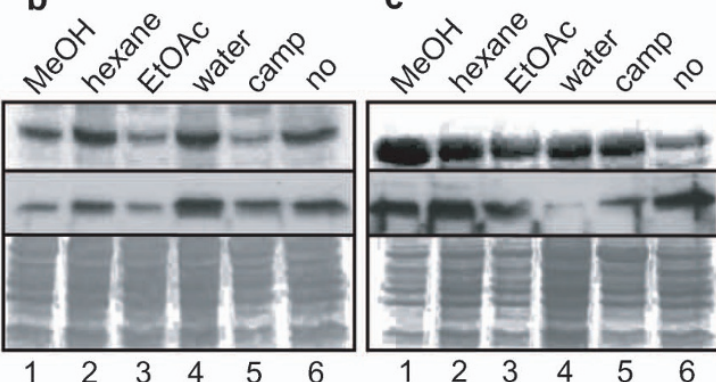

Figure 3 Activation of caspases in oral carcinoma cells by treatment with fractions prepared from Zelkova serrata twigs. Cells originated from mouth epidermoid carcinoma (a), lower gingival squamous cancer (b) and tongue mucoepidermoid carcinoma (c) were treated with each fractions of twig extract, and the total cell lysates were subjected to western blot analysis with the indicated antibodies, which were specific to procaspases. Lanes 1 , primary methanol extract of twigs; lanes 2 , hexane fraction from secondary partitioning of methanol extract; lanes 3 , ethyl acetate (EtOAc) fraction from secondary partitioning of methanol extract; lanes 4 , water fraction from secondary partitioning of methanol extract; lanes 5 , treatment with $10 \mu \mathrm{mol} \cdot \mathrm{L}^{-1}$ of camptothecin as a apoptosis positive control; lanes 6 , untreated control.

types of oral carcinomas. By performing p $53 \mathrm{cDNA}$ sequence analysis, we found that both mouth epidermoid carcinoma $(\mathrm{KB})$ and tongue mucoepidermoid carcinoma (YD15) cells contained wild-type p53 gene, whereas lower gingival squamous carcinoma (YD38) cells did not contain the $p 53$ gene due to deletion (Figure $5 \mathrm{a}$ ). In addition to $p 53$ gene status, $\mathrm{p} 53$ protein expression was also detected by Western blot. Under the conditions of treatment with the EtOAc fraction, p53 protein expression was strongly induced in mouth epidermoid carcinoma cells (Figure 5b, lane 2 in upper panel). However, although the p53 gene was determined to be wild-type without any mutation, $\mathrm{p} 53$ protein expression in tongue mucoepidermoid carcinoma cells was not induced by treatment with the EtOAc fraction. Interestingly, the basal level of endogenous 553 protein in tongue mucoepidermoid carcinoma cells was much higher than that in mouth epidermoid carcinoma cells, indicating that p53 protein expression in tongue mucoepidermoid carcinoma cells was not inducible and that these cells contained a much amount of p53 protein even under normal conditions (Figure 5b, lanes 3 and 4 in upper panel). As expected, p53 protein

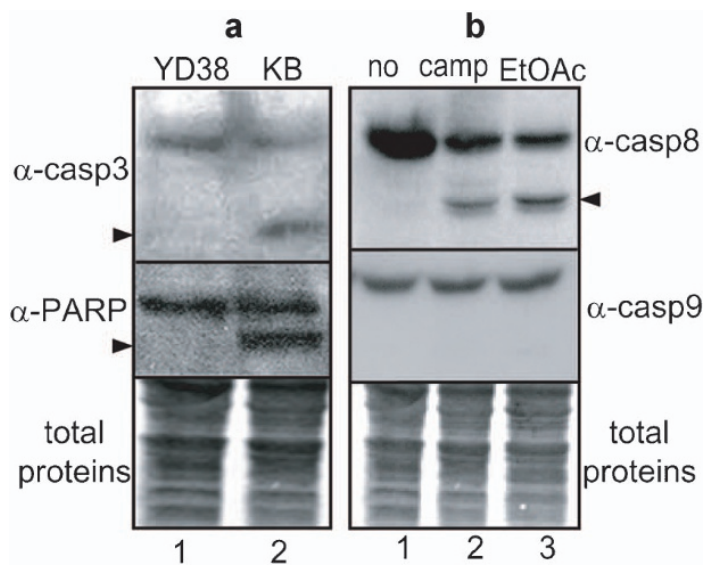

Figure 4 EtOAc fraction from twig extract induced an internal apoptotic pathway in mouth epidermoid carcinoma cells. (a) Treatment of EtOAc fraction induced the active cleavages of caspase-3 and PARP-1 in epidermoid carcinoma cells (lane 2, KB), not in lower gingival squamous cancer cells (lane 1, YD38). (b) Treatment of EtOAc fraction induced the active cleavages of caspase- 8 $(\alpha$-casp8), but not that of caspase- 9 ( $\alpha$-casp9) in mouth epidermoid carcinoma cells. Lane 1 , untreated control; lane 2 , treatment with $10 \mu \mathrm{mol} \cdot \mathrm{L}^{-1}$ of camptothecin; lane 3 , treatment with $20 \mathrm{ng} \cdot \mu \mathrm{L}^{-1}$ of EtOAc fraction. was not detected in lower gingival squamous carcinoma (YD38) cells upon either EtOAc fraction treatment or non-treatment (Figure 5b, lanes 5 and 6 in upper panel), as the p53 gene was deleted.

Generally, phosphorylation is important to the activation of $\mathrm{p} 53$, and specific residues in $\mathrm{p} 53$ are phosphorylated by specific upstream protein kinases and activation signals. ${ }^{24-26}$ To investigate the functional mechanism of p53 in modulating apoptosis upon treatment with the EtOAc fraction of $Z$. serrata twigs, we observed phosphorylation of p53 upon treatment with the EtOAc fraction using

a

\begin{tabular}{|c|c|c|}
\hline & Cell lines & p53 gene \\
\hline KB & mouth epthelial carcinoma & wild type \\
\hline YD15 & mucoepidermoid carcinoma & wild type \\
\hline YD38 & low gingiva squamous carcinoma & deleted \\
\hline
\end{tabular}
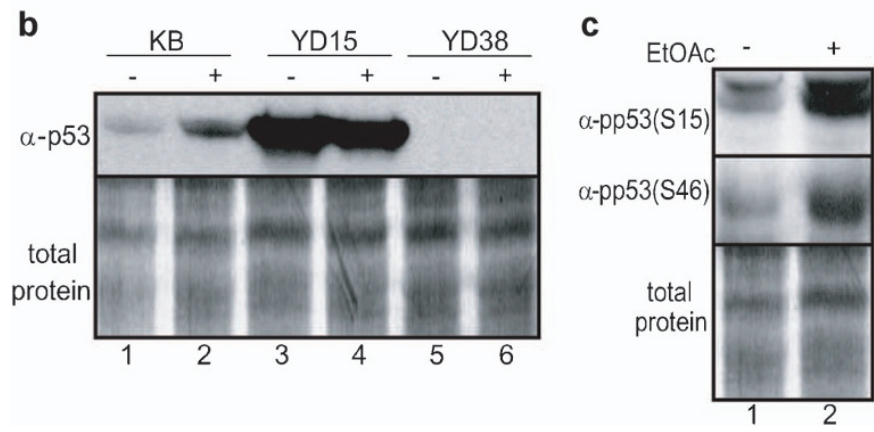

Figure 5 Features of p53 in three different oral cancer cell lines. (a) By DNA sequence analysis of $p 53$ cDNAs prepared from oral cancer cells, endogenous p53 gene in both mouth epidermoid carcinoma (KB) and tongue mucoepidermoid carcinoma (YD15) was wild type. In contrast, p53 gene was deleted in lower gingival squamous cancer (YD38) by deletion mutation. (b) The expression level of p53 protein in three different oral cancer cell lines as described in (a). Total cell extracts were prepared from cells untreated with EtOAc fraction (lanes 1, 3 and 5) and from those treated with EtOAc fraction (lanes 2, 4 and 6), and were subjected to Western blot analysis with anti-p53 specific antibody ( $\alpha$-p53). (c) The phosphorylations on Serine- 15 and -46 of p53 were increased by treatment with EtOAc fraction in mouth epidermoid carcinoma (KB) cells. Total cell extracts were prepared from cells untreated with EtOAc fraction (lane 1 ) and from those treated with EtOAc fraction (lane 2), and were subjected to Western blot analysis with phosphor-specific antibodies of p53. 
phospho-specific p53 antibodies during Western blot analysis. The phosphorylation of Ser-15 and Ser-46 increased upon treatment with the EtOAc fraction (Figure $5 c$, lanes 2 in upper and middle panels). These data indicate that treatment with twig extract in $\mathrm{KB}$ cells induced phosphorylation and activation of p53, resulting in apoptosis.

\section{Z. serrata twig extract disturbed cell division cycle}

To validate the role of the EtOAc fraction in disturbing cell division, fluorescence-activated cell sorter analysis was performed. For this, we examined the DNA content of cells after reaction with $7 \mathrm{ng} \cdot \mu \mathrm{L}^{-1}$ of the EtOAc fraction for $18 \mathrm{~h}$, which were mild treatment conditions. In unsynchronous culture of KB, YD15 and YD38, cells were mainly in $\mathrm{G}_{1} / \mathrm{S}$ phase $(70.4 \%, 70.4 \%$ and $71.5 \%$, respectively), whereas a small population of cells was in $\mathrm{G}_{2} / \mathrm{M}$ phase $(29.6 \%, 29.6 \%$ and $28.5 \%$, respectively) (Figure 6a, upper panels). As shown in Figure 6, treatment with the EtOAc fraction induced accumulation of KB and YD15 cells in S phase from $10.9 \%$ to $41.8 \%$ and $10.9 \%$ to $56.9 \%$, respectively (Figure $6 \mathrm{a}, \mathrm{KB}$ and YD15). The percentages of $\mathrm{G}_{2} / \mathrm{M}$ phase cells in both cultures dramatically decreased from $29.6 \%$ to $6.7 \%$ and $29.6 \%$ to $5.9 \%$, respectively (Figure $6 \mathrm{a}, \mathrm{KB}$ and $\mathrm{YD} 15$ ). However, lower gingival squamous carcinoma (YD38) cells did not display disturbance of the cell cycle, and there were no remarkable changes in the percentages of cells in $G_{1}, S$ or $G_{2} / M$ phase with and without treatment with EtOAc fraction (Figure 6a, YD38). To investigate the mechanism through which the twig EtOAc fraction disturbs the cell division cycle, the expression level of $\mathrm{p} 21^{\text {Waf1/Cip1 }}$, a cdk inhibitor, was measured. Expression of p21 protein increased upon treatment with the EtOAc fraction in both mouth epidermoid and tongue mucoepidermoid carcinoma cells (Figure 6b, lanes 2 and 4). Induction of p21 protein in gingival squamous carcinoma cells did not significantly increase upon EtOAc fraction treatment (Figure 6b, lane 6).

a KB

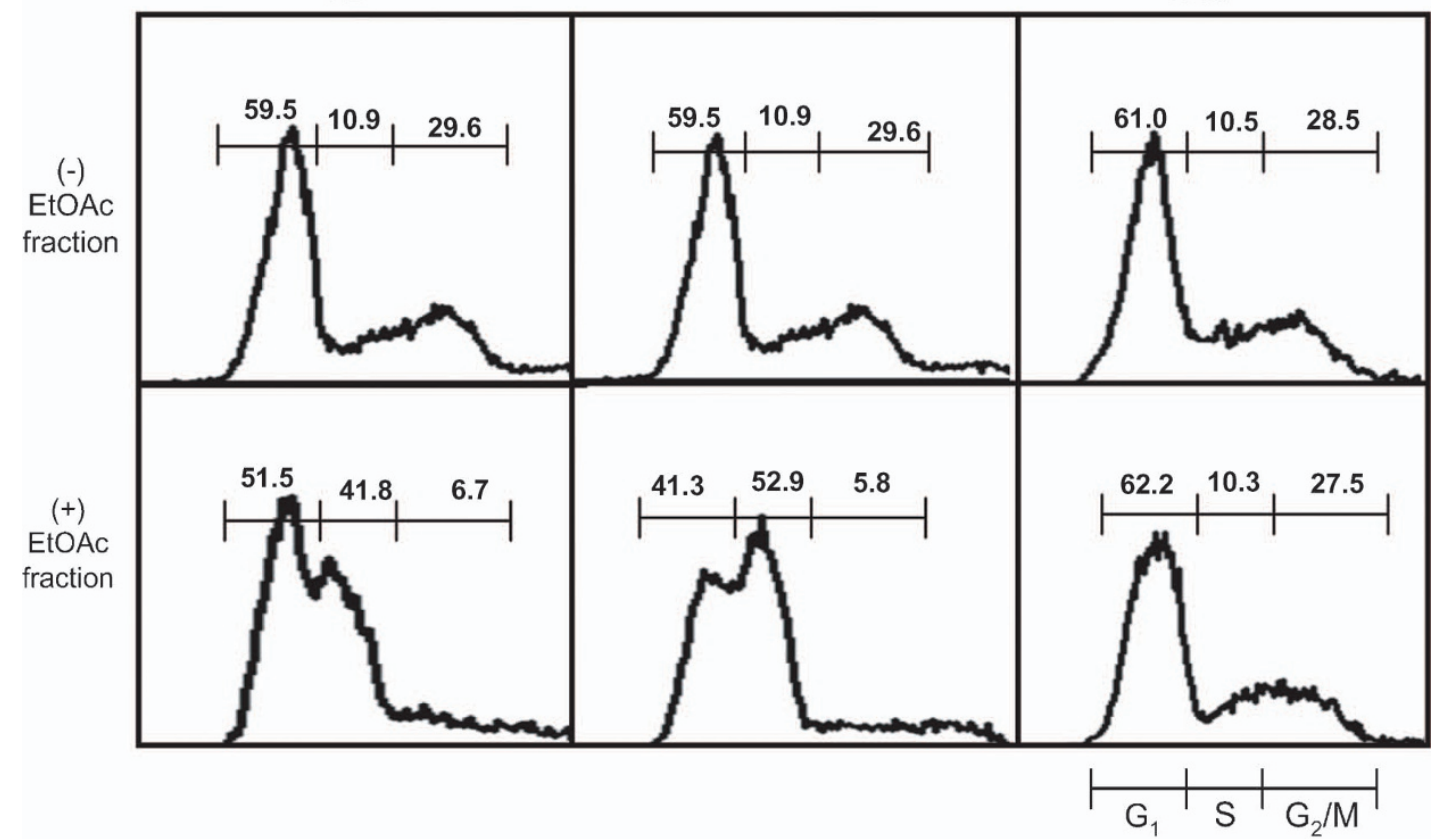

b

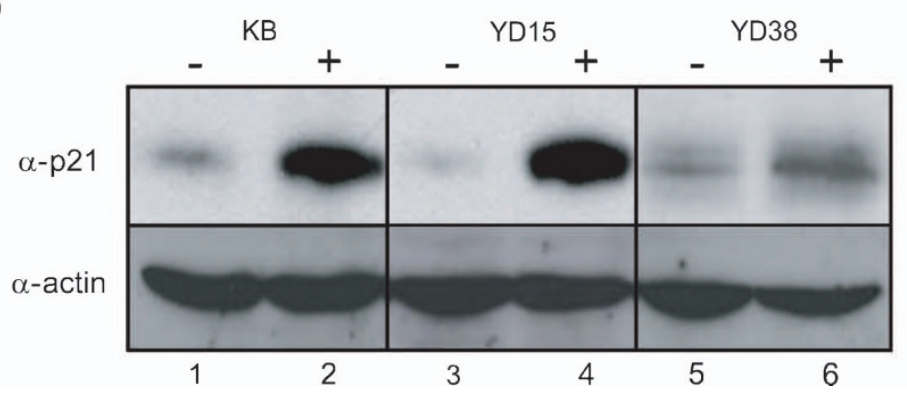

Figure 6 Treatment of EtOAc fraction of Zelkova serrata twig disturbed cell division cycle in cells originated from mouth epidermoid and tongue mucoepidermoid carcinomas. (a) FACS analysis of cell cycle distribution. DNA content of oral cancer cells in untreated $(-)$ or treated $(+)$ with $7 \mathrm{ng} \cdot \mu \mathrm{L}^{-1}$ of EtOAc fraction for $18 \mathrm{~h}$ was determined by flow cytometry. After fixation of cells with $70 \%$ ethanol for $24 \mathrm{~h}$, DNA was stained by adding propidium iodide. The population of cells in $\mathrm{G}_{1}, \mathrm{~S}$ and $\mathrm{G}_{2} / \mathrm{M}$ phase is indicated. (b) Effect of EtOAc fraction of Zelkova serrata twig on p21 expression. Total cell extracts were prepared from cells untreated with EtOAc fraction (lanes 1, 3 and 5) and from those treated with EtOAc fraction (lanes 2, 4 and 6), and were subjected to Western blot analysis with anti-p21 Waf1/Cip1 antibody $\alpha$-p21). In (a) and (b), KB, YD15 and YD38 indicated mouth epidermoid carcinoma cells, tongue mucoepidermoid carcinoma cells and lower gingival squamous cancer cells, respectively. FACS, fluorescence-activated cell sorter analysis. 


\section{DISCUSSION}

Oral cancer, a subtype of head and neck cancer, is any cancerous tissue growth located in the oral cavity. ${ }^{27}$ Oral cancer was reportedly diagnosed in almost 35310 US adults in 2008. Oral or mouth cancer most commonly occurs on the tongue, but may also occur on the cheek lining, gingival (gums) or lips. Based on this information, we chose three different types of oral cancer cell lines, mouth epidermoid carcinoma, lower gingival squamous carcinoma and tongue mucoepidermoid carcinoma, and investigated the anti-cancer effect of a natural product originating from $Z$. serrata. Interestingly, the molecular aspects of $p 53$ tumor suppressor protein were remarkably different among these three cell lines. Whereas lower gingival squamous carcinoma was a $p 53$-deletion mutant, $p 53$ gene in both mouth epidermoid and tongue mucoepidermoid carcinoma cells did not contain any mutations, as determined by cDNA sequencing. Although the gene status of p53 was normal, its protein expression level was extremely high and was not controlled at all in tongue mucoepidermoid carcinoma cells (Figure 5). Due to the differences in p53 expression, we expect that the three carcinoma cell types could differ in their response to an anti-cancer agent. So far, apoptotic inducers have been used in cancer therapy, as the apoptotic pathway is frequently impaired in many cancers. Several studies have attempted to induce apoptosis in cancer cells by triggering cell death proteins directly and indirectly, ${ }^{28-29}$ and some of these approaches have shown promising results. Previously, we analyzed the cytotoxic effects of crude extracts from 35 natural local plants on various cancer cell lines. ${ }^{22} Z$. serrata is called Keyaki or Japanese Zelkova and is native to Japan, Korea, Taiwan and eastern China. Traditionally, in Korea, crude extract of Z. serrata is known to exhibit anti-inflammatory and anti-cancer properties. Recently, a secondary metabolite classified as a flavonoid, cadalene, was isolated from whole tree and bark ethanol extract of $Z$. serrata Makino, and this compound was shown to exert anti-oxidative effects in mice. ${ }^{30}$ In this report, we used only twigs from whole tree to prepare the extract. Methanol extract of the twig powder showed cancer cellspecific cytotoxicity (Figure 1 ). The average $\mathrm{IC}_{50}$ value of methanol extract in oral cancer cells was about $200-250 \mathrm{ng} \cdot \mu \mathrm{L}^{-1}$. After partitioning this methanol extract with hexane, ethyl acetate and water, the EtOAc fraction showed cancer cell-specific cytotoxicity (Figure 2). The $\mathrm{IC}_{50}$ value of the EtOAc fraction $\left(\sim 20 \mathrm{ng} \cdot \mu \mathrm{L}^{-1}\right)$ was about 10 times higher than that of primary methanol extract, indicating that the ingredient possessing cytotoxicity could be enriched by purification. Interestingly, this fraction modulated caspase activation in only $\mathrm{KB}$ epidermoid carcinoma cells (Figure $3 \mathrm{a}$ ) and had no remarkable apoptotic effects on either gingival squamous or tongue mucoepidermoid carcinoma cells (Figure $3 \mathrm{~b}$ and $3 \mathrm{c}$ ). Additionally, the EtOAc fraction induced the external apoptotic pathway involving caspases- 8 and -3 (Figure $4 \mathrm{~b}$ ), indicating that this fraction possibly modulates cell surface death receptors by ligand stimulation. Generally, induction of p53 tumor suppressor initiates blockage of the cell division cycle and apoptosis. Indeed, only in mouth epidermoid carcinoma cells, both expression and modification of $\mathrm{p} 53$ protein markedly increased upon treatment with $20 \mathrm{ng} \cdot \mu \mathrm{L}^{-1}$ of EtOAc fraction of $Z$. serrata twigs (Figure $5 \mathrm{~b}$ and $5 \mathrm{c}$ ), indicating that apoptosis induced by EtOAc fraction treatment is dependent on the induction and activation of p53. In addition to apoptosis induction, the percentage of cells in $S$ phase increased, and $\mathrm{G}_{2} / \mathrm{M}$ populations of $\mathrm{KB}$ cells dramatically decreased upon treatment with the EtOAc fraction. These data indicate that induction and activation of p53 modulate cell cycle disturbance. To further investigate how twig extract induced cells to arrest in $G_{1}-S$ phase, we examined changes in the level of $\mathrm{p} 21^{\text {Wafl/Cip1 }}$, which is a target gene of $\mathrm{p} 53$ and a major factor in $\mathrm{G}_{1}-\mathrm{S}$ arrest in response to stress. ${ }^{16-18}$ The results show that the expression of $\mathrm{p} 21^{\text {Waf1/Cip1 }}$ was upregulated by treatment with the EtOAc fraction in $\mathrm{KB}$ cells (Figure 6b, lanes 1 and 2). Although expression of p53 was not controlled in YD15 tongue mucoepidermoid carcinoma cells, $\mathrm{p} 21$ protein increased upon treatment with the EtOAc fraction, and cell proliferation was disturbed (Figure 6a and lanes 3 and 4 in Figure 6b), which indicates that tongue mucoepidermoid carcinoma cells might express p21 in a p53-independent manner. ${ }^{31-32}$ Due to p53-deletion and lower expression of $\mathrm{p} 21$, treatment with the EtOAc fraction of $Z$. serrata did not stimulate cell cycle arrest or apoptosis in YD38 gingival carcinoma cells (Figure 6a and lanes 5 and 6 in Figure 6b). In conclusion, partially purified fraction of $Z$. serrata twigs exerted a selective apoptotic effect on mouth epidermoid carcinoma cells, which express functional p53, by inducing $\mathrm{p} 21^{\text {Wafl/Cip } 1}$ expression. In addition, induction of cancer type-specific apoptosis by $Z$. serrata twig extract suggests that this material could be developed as a promising p53-dependent cancer therapeutic agent in the future.

\section{ACKNOWLEDGEMENTS}

We are greateful to Mun Chul Rho (Korea Research Institute of Bioscience \& Biotechnology) and Chung Berm Park (Rural Development Administration) for helping preparation of $Z$. serrata twig extract. This work was supported by Dankook University Research Grant (2011).

1 Warnakulasuriya S. Global epidemiology of oral and oropharyngeal cancer. Oral Oncol 2009; 45(4/5): 309-316.

2 Petersen PE. Oral cancer prevention and control-the approach of the World Health Organization. Oral Oncol 2009; 45(4/5): 454-460.

3 Warnakulasuriya S. Living with oral cancer: epidemiology with particular reference to prevalence and life-style changes that influence survival. Oral Oncol 2010; 46(6): 407-410.

4 Taylor RC, Cullen SP, Martin SJ. Apoptosis: controlled demolition at the cellular level. Nat Rev Mol Cell Biol 2008; 9(3): 231-241.

5 Danial NN, Korsmeyer SJ. Cell death: critical control points. Cel/2004; 116(2): 205219.

6 Wajant $\mathrm{H}$. The Fas signaling pathway: more than a paradigm. Science 2002; 296(5573): 1635-1636

7 RiedI SJ, Salvesen GS. The apoptosome: signalling platform of cell death. Nat Rev Mol Cell Biol 2007; 8(5): 405-413.

8 Spierings D, McStay G, Saleh M et al. Connected to death: the (unexpurgated) mitochondrial pathway of apoptosis. Science 2005; 310(5745): 66-67.

9 Sharpless NE, DePinho RA. p53: good cop/bad cop. Cel/ 2002; 110(1): 9-12.

10 Vousden KH, Prives C. Blinded by the light: the growing complexity of p53. Cel/2009; 137(3): 413-431.

11 Vogelstein B, Lane D, Levine AJ. Surfing the p53 network. Nature 2000; 408(6810): 307-310.

12 Feng Z, Levine AJ. The regulation of energy metabolism and the IGF-1/mTOR pathways by the p53 protein. Trends Cell Biol 2010; 20(7): 427-434.

13 Symonds $\mathrm{H}$, Krall L, Remington L et al. p53-dependent apoptosis suppresses tumor growth and progression in vivo. Cell 1994; 78(4): 703-711.

14 Donehower LA, Harvey M, Slagle BL et al. Mice deficient for p53 are developmentally normal but susceptible to spontaneous tumours. Nature 1992; 356(6366): 215221.

15 Jacks T, Remington L, Williams BO et al. Tumor spectrum analysis in p53-mutant mice. Curr Biol 1994; 4(1): 1-7.

16 Deng C, Zhang P, Harper JW et al. Mice lacking p21CIP1/WAF1 undergo normal development, but are defective in $\mathrm{G}_{1}$ checkpoint control. Cell 1995; 82(4): 675-684.

17 Brugarolas J, Chandrasekaran C, Gordon JI et al. Radiation-induced cell cycle arrest compromised by p21 deficiency. Nature 1995; 377(6549): 552-557.

18 Gartel AL. The conflicting roles of the cdk inhibitor p21 $1^{\text {CIP1/WAF1 }}$ in apoptosis. Leuk Res 2005; 29(11): 1237-1238.

19 World Agroforestry Centre. Agroforestree Database. A Tree Reference and Selection Guide Version 4.0 [Internet]. Nairobi: World Agroforestry Centre; 2009 [cited 5 December 2011]. Available from http://www.worldagroforestry.org/treedb.

20 Jin H, Kim HW, Xu CX et al. Effects of 7-hydroxy-3-methoxycadalene on cell cycle, apoptosis and protein translation in A549 lung cancer cells. Biofactors 2007; 29(2/3): 67-75.

21 Kim JH, Lee HJ, Kim GS et al. Inhibitory effects of 7-hydroxy-3-methoxy-cadalene on 4-(methylinitrosamino)-1-(3-pyridyl)-1-butanone (NNK)-induced lung tumorigenesis in A/J mice. Cancer Lett 2004; 213(2): 139-145. 
22 Yoon YK, Lee HJ, Kim GS et al. Anti-cancer activity of Korean local plant extracts inducing apoptosis in various carcinoma cells. Korean J Pharmacogn 2009; 40(8): $6-12$.

23 Jang YJ, Ji JH, Choi YC et al. Regulation of Polo-like kinase 1 by DNA damage in mitosis. Inhibition of mitotic PLK-1 by protein phosphatase 2A. J Biol Chem 2007 ; 282(4): 2473-2482.

24 van Dieck J, Teufel DP, Jaulent AM et al. Posttranslational modifications affect the interaction of S100 proteins with tumor suppressor p53. J Mol Biol 2009; 394(5): 922-930.

25 Saito S, Goodarzi AA, Higashimoto Y et al. ATM mediates phosphorylation at multiple p53 sites, including $\mathrm{Ser}^{46}$, in response to ionizing radiation. J Biol Chem 2002 ; 277(15): 12491-12494.

26 D'Orazi G, Cecchinelli B, Bruno T et al. Homeodomain-interacting protein kinase-2 phosphorylates p53 at $\mathrm{Ser}^{46}$ and mediates apoptosis. Nat Cell Biol 2002; 4(1): $11-19$.

27 Werning JW. Oral Cancer: Diagnosis, Management, and Rehabilitation. New York: Thieme, 2007.

28 Reed JC. Apoptosis-based therapies. Nat Rev Drug Discov 2002; 1(2): 111-121.
$29 \mathrm{Hu}$ W, Kavanagh JJ. Anticancer therapy targeting the apoptotic pathway. Lancet Oncol 2003; 4(12): 721-729.

$30 \mathrm{Kim} \mathrm{JH}$, Lee HJ, Yeon SC et al. Antioxidative effects of 7-hydroxy-3-methoxy-cadalene extracted from Zelkova serrata on 4-(methylinitros amino)-1-(3-pyridyl)-1-butanoneinduced oxidative stress in A/J mice. Phytother Res 2004; 18(5): 425-427.

31 Mahyar-Roemer M, Roemer K. p2 $1^{\text {Waf1/Cip } 1}$ can protect human colon carcinoma cells against p53-dependent and p53-independent apoptosis induced by natural chemopreventive and therapeutic agents. Oncogene 2001; 20(26): 3387-3398.

32 Datto MB, Li Y, Panus JF et al. Transforming growth factor beta induces the cyclindependent kinase inhibitor p21 through a p53-independent mechanism. Proc Natl Acad Sci U S A 1995; 92(12): 5545-5549.

(c) This work is licensed under a Creative Commons Attribution-NonCommercial-NoDerivative Works 3.0 Unported License. To view a copy of this license, visit http:// creativecommons.org/licenses/by-nc-nd/3.0 